\title{
Intra-day variations of blood reelin levels in healthy individuals
}

\author{
Lukas Sturm ${ }^{1}$, Ludger Tebartz van Elst ${ }^{1}$, Bernd Fiebich ${ }^{1}$, Martin Wolkewitz ${ }^{2}$, Tobias Hornig ${ }^{1}$
}

\begin{abstract}
${ }^{1}$ Department of Psychiatry, University Hospital Freiburg, Freiburg, Germany 2Department of Medical Biometrics and Medical Informatics, University of Freiburg, Freiburg, Germany
\end{abstract}

Submitted: 4 July 2017

Accepted: 7 August 2017

Arch Med Sci 2020; 16 (1): 118-123

DOI: https://doi.org/10.5114/aoms.2020.91288

Copyright $\odot 2019$ Termedia \& Banach

\section{Abstract}

Introduction: Reelin (RELN) is an extracellular glycoprotein best known to be crucial for neuronal migration during the embryonic period and regulation of synaptic plasticity in the adult brain, with recent studies pointing to reelin playing an important part in the organization of peripheral organs as well. Abnormalities in RELN function are associated with a variety of medical conditions in human beings. These alterations partly also reflect in RELN's blood levels, which gives it a clinical relevance as a potential biomarker. Requirement for a possible clinical use is a profound understanding of RELN's physiology. We hypothesized blood RELN levels could underlie time-dependent variations and therefore examined individuals' serum reelin concentrations in the course of one day.

Material and methods: We obtained blood samples from healthy individuals $(n=10)$ at several times of measurement over a time period of $24 \mathrm{~h}$. We subsequently determined the respective serum RELN concentrations utilizing an enzyme-linked immunosorbent assay and tested for intra- and interindividual variations in serum RELN concentrations over time.

Results: All tested individuals' serum RELN levels displayed significant intraindividual variations in the course of $24 \mathrm{~h}$. Test subjects' reelin day profiles showed substantial divergence among each other.

Conclusions: Our findings point to short-term fluctuations in blood RELN levels being part of physiological RELN homeostasis. This is of special interest with regard to a potential clinical use of RELN as a biomarker.

Key words: serum, enzyme-linked immunosorbent assay, fluctuations.

\section{Introduction}

Reelin (RELN) is a secreted extracellular glycoprotein with a size of about $410 \mathrm{kDa}$ that is highly conserved among vertebrate species [1, 2].

RELN is a ligand to two transmembrane receptors of the low-density-lipoprotein receptor family, the apolipoprotein E receptor 2 (ApoER2) and the very-low-density-lipoprotein receptor (VLDLR). Upon binding to its target receptors RELN is ingested into the cell, initiating a downstream signaling cascade based on Disabled 1 (Dab1) dependent src-family kinase phosphorylation [3-5].

During the embryonic period RELN is particularly found in Cajal-Retzius-cells in the cortex' marginal zone where it acts as a start-stop-signal in neuronal migration and affects cytoskeletal dynamics by interaction

\author{
Corresponding author: \\ Dr. Lukas Sturm \\ Department \\ of Psychiatry \\ University Hospital \\ Hugstetter Str. 55 \\ 79106 Freiburg, Germany \\ Phone: +49 17621054134 \\ E-mail: lukas.sturm.med@ \\ uniklinik-freiburg.de
}


with motor proteins such as dynein via the ApoER2/VLDLR signaling cascade [6-11]. Knock-out mice lacking RELN therefore display severe abnormalities in the architecture of the whole brain, inter alia inversed histological layer formation of the whole neocortex, reduced numbers of dendritic spines in the hippocampus and an atrophied cerebellum [12-14]. In the adult brain RELN is mainly expressed by GABA-ergic interneurons [6]. It regulates the activity of glutamatergic hippocampal synapses by interaction with NMDA and AMPA receptors and stimulates dendrite proliferation through interaction with transcription factors such as CREB. Thereby RELN is crucial for synaptic plasticity and learning processes. Reelin-deficient mice show severe deficits in long-term potentiation and cognitive learning [15-21].

Recent studies discovered RELN in peripheral organ systems as well. It has been found inter alia in human blood, liver, pancreas, mamma and intestines [22-26].

Alterations in RELN function are associated with several medical conditions in human beings. Amongst these are neuropsychiatric disorders such as schizophrenia, lissencephaly and Alzheimer's disease as well as a variety of other diseases, for instance cancerous diseases [24-26]. In schizophrenia for example, epigenetic changes lead to downregulation of cerebral RELN expression, while a mutation in the RELN gene is responsible for an autosomal recessive form of lissencephaly [27-31].

These associations make RELN come into question as a potential biomarker for diseases in humans. Hence, the protein's serum and plasma levels have been subject to a number of studies carried out to investigate correlations with different pathological findings, summarized in Table I.

To be able to interpret the findings of these studies and as a key premise for a potential use of reelin as a biomarker it is crucial to learn more about RELN's physiology in the bloodstream. Therefore we examined whether there are variations in healthy individuals' serum RELN levels in the course of $24 \mathrm{~h}$. Actually our study is the first in the international literature to investigate variations in blood reelin levels over time.

\section{Material and methods}

\section{Test subjects}

We acquired ten healthy test subjects (six male, four female) aged between 24 and 30 years. All subjects were required not to meet a set of exclusion criteria including any severe acute or chronic disease, current medication intake, drug or alcohol abuse and pregnancy.

\section{Experimental setup}

From all test persons eight blood samples each were obtained in the course of $24 \mathrm{~h}$. Samples were gained at intervals of $3 \mathrm{~h}$, starting at 8:00. To achieve the best possible comparability among test subjects, testings were carried out according to a set framework. Participants were obliged to get up at 8:00 and go to sleep at 0:00. Meals were eaten at 9:00, 12:00 and 18:00. Exceptional mental or physical stress was avoided. No alcohol, nicotine, caffeine or other drugs were consumed.

\section{Ethics statement}

Prior to commencing the study approval from the Albert Ludwig University of Freiburg's ethics committee was acquired (no. 335/13). Test subjects gave written consent to participate in the study.

\section{Enzyme-linked immunosorbent assay}

The venous blood samples were obtained in standard serum test tubes, centrifuged and the serum samples stored at $-80^{\circ} \mathrm{C}$. Subsequently the samples' RELN concentrations were determined using a sandwich ELISA by Cusabio. The assay's upper detection limit is $10 \mathrm{ng} / \mathrm{ml}$ RELN at a sensitivity of $<0.039 \mathrm{ng} / \mathrm{ml}$. Samples with RELN concentrations below that range were therefore approximated as $0 \mathrm{ng} / \mathrm{ml}$. The assay is highly specific for human reelin; no significant cross reactivities were observed. Spike recovery testing and linearity testing accounted for an average of $103 \%$ and $98 \%$, respectively, in human serum. Intra- and inter-assay coefficients of variation, determined by twentyfold testing of three reference samples on one plate or on different plates, respectively, are $<8 \%$ and $<10 \%$. Hence the assay is very precise with little scattering. Epitope mapping was not performed.

The standard series was obtained by performing six $1: 2$ dilution steps starting with a high standard with an antigen concentration of $10 \mathrm{ng} /$ $\mathrm{ml}$ (thus resulting in concentrations of $5 \mathrm{ng} / \mathrm{ml}$, $2.5 \mathrm{ng} / \mathrm{ml}, 1.25 \mathrm{ng} / \mathrm{ml}, 0.625 \mathrm{ng} / \mathrm{ml}, 0.312 \mathrm{ng} / \mathrm{ml}$, $0.156 \mathrm{ng} / \mathrm{ml}$ ). A solution with a concentration of $0 \mathrm{ng} / \mathrm{ml}$ served as a zero standard.

$100 \mu \mathrm{l}$ of a sample or standard at a time were pipetted into the wells of a $12 \times 8$ polystyrene microtiter plate precoated with a human reelin-specific monoclonal mouse antibody and incubated for $2 \mathrm{~h}$ at $37^{\circ} \mathrm{C}$. After removal of supernatant $100 \mu \mathrm{l}$ of a solution containing biotinylated polyclonal goat antibody specific for human reelin was added to each well and incubated for $1 \mathrm{~h}$ at $37^{\circ} \mathrm{C}$. Unbound detection antibody was thereafter removed by applying $200 \mu \mathrm{l}$ of wash buffer and aspirating three times per well. Subsequently $100 \mu \mathrm{l}$ of avidin-bound HRP (horseradish peroxidase) solution were added to each well and incubat- 
Table I. Summary of findings on altered levels of RELN and its isoforms in serum or plasma

\begin{tabular}{|c|c|c|c|c|c|}
\hline Author, year & Method & Issue & RELN conc. serum/plasma & $\begin{array}{l}\text { RELN } \\
\text { conc. } \\
\text { tissue }\end{array}$ & $\begin{array}{l}\text { RELN } \\
\text { mRNA } \\
\text { conc. } \\
\text { tissue }\end{array}$ \\
\hline $\begin{array}{l}\text { Fatemi et al., } \\
2001\end{array}$ & Immunoblot & $\begin{array}{c}\text { RELN levels in } \\
\text { schizophrenia/mood } \\
\text { disorders }\end{array}$ & $\begin{array}{c}\text { Schizophrenia: } \\
\text { Pat. }(n=16) \text { vs. contr. }(n=8) \uparrow \\
p<0.02(410 \mathrm{kDa}) \\
\text { Bipolar disorder: } \\
\text { Pat. }(n=5) \text { vs. contr. }(n=8) \downarrow \\
p<0.048(310 \mathrm{kDa}) \\
\text { Major depression: } \\
\text { Pat. }(n=4) \text { vs. contr. }(n=8) \downarrow \\
p<0.04(180 \mathrm{kDa})\end{array}$ & $\mathrm{n} / \mathrm{a}$ & $\mathrm{n} / \mathrm{a}$ \\
\hline $\begin{array}{l}\text { Botella-López } \\
\text { et al., } 2006\end{array}$ & Immunoblot & $\begin{array}{l}\text { RELN levels in } \\
\text { Alzheimer's disease }\end{array}$ & $\begin{array}{c}\text { Pat. }(n=12) \text { vs. contr. }(n=44) \rightarrow \\
p>0.05\end{array}$ & $\begin{array}{l}\uparrow \text { Brain } \\
\uparrow \mathrm{CSF}\end{array}$ & $\begin{array}{l}\uparrow \text { Brain } \\
\uparrow \mathrm{CSF}\end{array}$ \\
\hline $\begin{array}{l}\text { Botella-López } \\
\text { et al., } 2008\end{array}$ & Immunoblot & $\begin{array}{l}\text { RELN levels in patients } \\
\text { with liver cirrhosis }\end{array}$ & $\begin{array}{c}\text { Pat. }(n=8) \text { vs. contr. }(n=12) \uparrow \\
p<0.001(180 \mathrm{kDa})\end{array}$ & $\uparrow$ Liver & $\mathrm{n} / \mathrm{a}$ \\
\hline $\begin{array}{l}\text { Magnani } \\
\text { et al., } 2010\end{array}$ & Immunoblot & $\begin{array}{l}\text { RELN levels in } \\
\text { rheumatoid arthritis }\end{array}$ & Pat. Vs. contr. $\uparrow$ & $\uparrow$ Synovia & $\uparrow$ Synovia \\
\hline $\begin{array}{l}\text { Brummelte } \\
\text { et al., } 2013\end{array}$ & Immunoblot & $\begin{array}{l}\text { RELN levels after } \\
\text { maternal SSRI intake } \\
\text { during pregnancy }\end{array}$ & $\begin{array}{c}\text { Exp. }(n=25) \text { vs. contr. }(n=42) \\
\text { Mothers: } \uparrow \\
p=0.047(310 \mathrm{kDa}) \\
\text { Newborns: } \\
\text { Female } \downarrow \\
p=0.002(310 \mathrm{kDa}) \\
\text { Male } \rightarrow \\
p=0.66\end{array}$ & $\mathrm{n} / \mathrm{a}$ & $\mathrm{n} / \mathrm{a}$ \\
\hline $\begin{array}{l}\text { Mansy et al., } \\
2014\end{array}$ & Immunoblot & $\begin{array}{l}\text { RELN levels in HCV } \\
\text { patients with liver } \\
\text { fibrosis }\end{array}$ & $\begin{array}{l}\text { Pat. }(n=74) \text { vs. contr. }(n=15) \uparrow \\
p \leq 0.001\end{array}$ & $\uparrow$ Liver & $\mathrm{n} / \mathrm{a}$ \\
\hline $\begin{array}{l}\text { Dazzo et al., } \\
2015\end{array}$ & Immunoblot & $\begin{array}{l}\text { RELN levels in } \\
\text { autosomal dominant } \\
\text { lateral temporal } \\
\text { epilepsy }\end{array}$ & $\begin{aligned} \text { Pat. }(n=4) \text { vs. contr. }(n=3) \downarrow \\
p=0.028(420 \mathrm{kDa})\end{aligned}$ & $\mathrm{n} / \mathrm{a}$ & $\mathrm{n} / \mathrm{a}$ \\
\hline $\begin{array}{l}\text { Hornig et al., } \\
2015\end{array}$ & ELISA & $\begin{array}{l}\text { RELN levels in first } \\
\text { episode schizophrenia }\end{array}$ & $\begin{array}{l}\text { Pat. }(n=20) \text { vs. contr. }(n=20) \uparrow \\
p=0.007\end{array}$ & $\mathrm{n} / \mathrm{a}$ & $\mathrm{n} / \mathrm{a}$ \\
\hline
\end{tabular}

Pat. - patient, contr. - control, CSF - cerebrospinal fluid. $\uparrow=$ increased, $\downarrow=$ decreased, $\rightarrow=$ not different, $n / a=$ not applicable.

ed for $1 \mathrm{~h}$ at $37^{\circ} \mathrm{C}$. Afterwards aspiration/washing was repeated five times. Then $90 \mu \mathrm{l}$ of TMB substrate (3,3',5, ''-tetramethylbenzidine) were added and incubated at $37^{\circ} \mathrm{C}$. The probes were protected from light. After $25 \mathrm{~min} 50 \mu \mathrm{l}$ of stop solution (1 $\mathrm{N}$ sulfuric acid) at a time were added. Within a period of $5 \mathrm{~min}$ the optical densities were determined using a Dynex MRX microplate reader set to a wavelength of $450 \mathrm{~nm}$. Samples and standards were then evaluated with the software Dynex Revelations.

\section{Statistical analysis}

The repeated measurements of each individual were graphically explored by plotting RELN concentrations against time. For better visualization the row values were log-transformed and the extreme values of one individual excluded. For exploring a time trend, we fitted a mixed effect model with the subjects as random and time as a continuous variable, studying polynomial trends. Using the whole row data set the Friedman test (a nonparametric counterpart of two-way analysis of variance) was performed to test for a significant time effect. The statistical software R (version 3.2.0) was used.

\section{Results}

\section{Variations in serum RELN levels}

RELN could be detected in all obtained blood samples. The test subjects' serum RELN levels did not only differ interindividually but showed considerable intraindividual variations over time (Figure 1). Except for one test subject displaying very high concentrations beyond the assay's detection range at two times of measurement, detected serum RELN levels ranged between $0.052 \mathrm{ng} / \mathrm{ml}$ and $1.23 \mathrm{ng} / \mathrm{ml}$. Test subjects showed different extents of intraindividual variation in their serum RELN concentrations over time, the slightest fluctuation ranging between $0.052 \mathrm{ng} / \mathrm{ml}$ and 0.072 


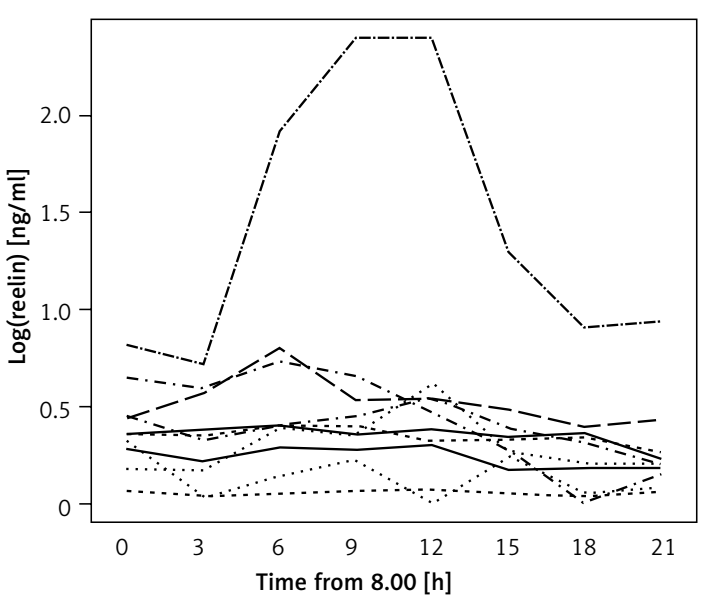

Figure 1. Test subjects' serum RELN day profiles. The lines depict the test subjects' serum RELN concentrations over time, showing significant intraindividual variations

$\mathrm{ng} / \mathrm{ml}$, differing by a factor of 1.38 , and the most distinct ranging between $0.161 \mathrm{ng} / \mathrm{ml}$ and 1.08 $\mathrm{ng} / \mathrm{ml}$, differing by a factor of 6.71 .

\section{Time effect}

The Friedman rank sum test showed a highly significant time effect for all tested individuals' serum RELN concentrations $(p=0.00014 ; \mathrm{d} f=7$; $\left.\chi^{2}=29.09\right)$.

Although a uniform trend in the variations of individuals' serum RELN levels was not recognizable the entirety of test subjects' RELN levels over time could be described as a linear function with a negative gradient $(c(t)=0.4689-0.00357 \times t)$, showing an overall slight decrease in serum RELN concentrations (Figure 2).

\section{Concentration peaks}

With respect to the starting time all but one test subjects' RELN levels increased in the course of our measurement to peak at one time of measurement. Although not statistically depictable, two groups could be distinguished: Four test subjects' RELN levels peaked at the third time of measurement at 14:00, while five test subjects' levels peaked at the fifth time of measurement at 20:00. The remaining test subject's peak was at 08:00.

\section{Discussion}

Our main finding was that healthy individuals' serum RELN levels displayed significant variations in the course of a day. This finding is highly interesting with respect to both exploring the physiology of RELN in peripheral blood as well as its possible clinical relevancy as a diagnostic marker. Unfortunately, still very little is known about the protein's physiology in the body's periphery in contrast to its better understood role in the central nervous

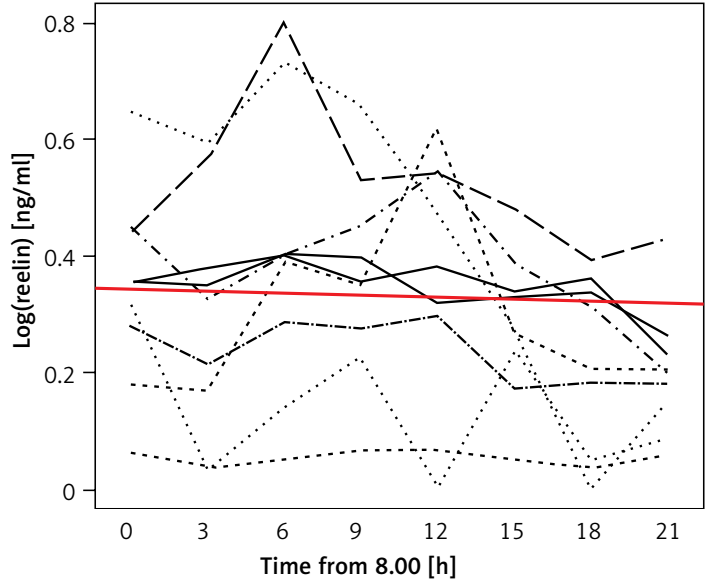

Figure 2. Linear function describing the entirety of serum RELN day profiles. The red line depicts a linear function $(c(t)=0.4689-0.00357 \times t)$ that describes the entirety of the test subjects' serum RELN day profiles. The function's negative gradient expresses a slight overall decrease in serum RELN in the course of our measurements

system, for which reason one can only speculate about the significance of our findings. However, several findings, such as cell damage leading to up-regulation of blood RELN levels or malfunction of the RELN pathway occurring in multiple cancerous diseases, point to RELN contributing to tissue organization and cell architecture in peripheral organs - comparable to its functions in the central nervous system [24-26, 32, 33]. This serves well to account for the permanent presence of RELN in the bloodstream, circulating to reach its target organs, but hardly explains the short-term fluctuations we observed. Yet, the fact that we found significant variations over time in all tested individuals' serum RELN levels points to these fluctuations being part of physiological RELN homeostasis. At the same time the abundance of a uniform trend in the variations suggests the regulation of blood RELN levels to be both highly individual and complex. Hormones and cytokines could be influencing factors among others. Animal models show that application of triiodothyronine (T3) and hepatocyte growth factor (HGF) increase cerebral RELN synthesis [34, 35]. Glucocorticoids in contrast inhibit hepatic RELN synthesis in vitro $[22,36]$. A link to cortisol metabolism could explain circadian changes in RELN levels. However, we observed no clear decline in RELN levels during the day (as you would expect opposite to cortisol levels). Future studies in vitro and in vivo will be necessary to identify effectors of blood RELN homeostasis.

We examined a rather small number of test subjects. Their serum RELN profiles being highly different, a higher number of test subjects could offer a greater chance of distinguishing regularities among the profiles. Furthermore, we acquired blood samples at relatively large intervals of $3 \mathrm{~h}$ 
for the limited time period of $24 \mathrm{~h}$, which gave us a sufficient number of points of measurement to acknowledge significant variations in blood RELN levels over time. However, smaller intervals in future works carried out over longer periods of time could help to establish a more precise picture of blood RELN dynamics. Our experiments were performed on a homogeneous set of test subjects according to a set framework ensuring comparability among them. Still, creating an even higher degree of standardization to eliminate disturbance variables would be necessary to clearly identify single factors affecting blood RELN homeostasis. This could for instance imply accommodating test subjects under strictly controlled conditions for the duration of measurements in order to monitor effects of environmental influences on blood RELN levels.

In conclusion, variations in its blood levels over time could be part of RELN's physiological homeostasis. Our study being the first in the international literature to investigate variations in blood RELN levels over time, future studies will have to confirm these findings and further illuminate RELN blood level profiles. A more profound understanding of RELN's physiology in blood is a key premise for a potential clinical use as a biomarker. Possible fluctuations in blood RELN levels will also have to be taken into account when interpreting existing or planning future studies investigating blood RELN levels.

We found significant inter- and intraindividual variations over time in healthy individuals' blood RELN levels, suggesting these fluctuations to be part of physiological RELN homeostasis. Intensified research will be necessary to gain a better understanding of RELN's physiology in peripheral blood, especially with respect to RELN's role as a possible biomarker for diseases in humans.

\section{Acknowledgments}

We would like to thank all test subjects who participated in our experiments.

This work was supported by the University Hospital Freiburg, Department of Psychiatry, Hauptstr. 5, 79104 Freiburg, Germany.

\section{Conflict of interest}

The authors declare no conflict of interest.

\section{References}

1. DeSilva U, D'Arcangelo G, Braden V, et al. The human reelin gene: isolation, sequencing, and mapping on chromosome 7. Genome Res 1997; 7: 157-64.

2. Lambert de Rouvroit C, de Bergeyck V, Cortvrindt C, Bar I, Eeckhout Y, Goffinet A. Reelin, the extracellular matrix protein deficient in reeler mutant mice, is pro- cessed by a metalloproteinase. Exp Neurol 1999; 156: 214-7.

3. Trommsdorff M, Borg J, Margolis B, Herz J. Interaction of cytosolic adaptor proteins with neuronal apolipoprotein $\mathrm{E}$ receptors and the amyloid precursor protein. J Biol Chem 1998; 273: 33556-60.

4. Hiesberger T, Trommsdorff M, Howell B, et al. Direct binding of reelin to VLDL receptor and ApoE receptor 2 induces tyrosine phosphorylation of Disabled-1 and modulates tau phosphorylation. Neuron 1999; 24: 481-9.

5. Howell B, Herrick T, Cooper J. Reelin-induced tryosine phosphorylation of Disabled 1 during neuronal positioning. Genes Develop 1999; 13: 643-8.

6. Alcántara S, Ruiz M, D'Arcangelo G, et al. Regional and cellular patterns of reelin mRNA expression in the forebrain of the developing and adult mouse. J Neurosci 1998; 18: 7779-99.

7. Dulabon L, Olson EC, Taglienti MG, et al. Reelin binds alpha3beta1 integrin and inhibits neuronal migration. Neuron 2000; 27: 33-44.

8. Assadi A, Zhang G, Beffert $U$, et al. Interaction of reelin signaling and Lis1 in brain development. Nat Genet 2003; 35: 270-6.

9. Jossin Y. Neuronal migration and the role of reelin during early development of the cerebral cortex. Mol Neurobiol 2004; 30: 225-52.

10. Suetsugu S, Tezuka T, Morimura T, et al. Regulation of actin cytoskeleton by mDab1 through N-WASP and ubiquitination of mDab1. Biochem J 2004; 384: e1-2.

11. Schmid R, Jo R, Shelton S, Kreidberg JA, Anton ES. Reelin, integrin and Dab1 interactions during embryonic cerebral cortical development. Cerebral Cortex 2005; 15: 1632-6.

12. Hamburgh M. Analysis of the postnatal developmental effects of "reeler", a neurological mutation in mice. A study in developmental genetics. Developm Biol 1963; 8: $165-85$

13. Caviness VS. Patterns of cell and fiber distribution in the neocortex of the reeler mutant mouse. J Compar Neurol 1976; 170: 435-47.

14. Niu S, Renfro A, Quattrocchi C, Sheldon M, D’Arcangelo G. Reelin promotes hippocampal dendrite development through the VLDLR/ApoER2-Dab1 pathway. Neuron 2004; 41: 71-84.

15. Weeber E, Beffert U, Jones C, et al. Reelin and ApoE receptors cooperate to enhance hippocampal synaptic plasticity and learning. J Biol Chem 2002; 277: 39944-52.

16. Beffert U, Weeber E, Durudas A, et al. Modulation of synaptic plasticity and memory by reelin involves differential splicing of the lipoprotein receptor Apoer2. Neuron 2005; 47: 567-79.

17. Chen Y. Reelin mdulates NMDA receptor activity in cortical neurons. J Neurosci 2005; 25: 8209-16.

18. Sinagra M. Reelin, very-low-density lipoprotein receptor, and apolipoprotein $\mathrm{E}$ receptor 2 control somatic NMDA receptor composition during hippocampal maturation in vitro. J Neurosci 2005; 25: 6127-36.

19. Beffert U, Durudas A, Weeber E, et al. Functional dissection of reelin signaling by site-directed disruption of Disabled-1 adaptor binding to apolipoprotein $\mathrm{E}$ receptor 2: distinct roles in development and synaptic plasticity. J Neurosci 2006; 26: 2041-52.

20. Qiu S, Zhao L, Korwek K, Weeber E. Differential reelin-induced enhancement of NMDA and AMPA receptor activity in the adult hippocampus. J Neurosci 2006; 26: 12943-55.

21. Brai E, Marathe S, Astori S, et al. Notch1 regulates hippocampal plasticity through interaction with the 
reelin pathway, glutamatergic transmission and CREB signaling. Front Cell Neurosci 2015; 9. https://doi. org/10.3389/fncel.2015.00447.

22. Smalheiser N, Costa E, Guidotti A, et al. Expression of reelin in adult mammalian blood, liver, pituitary pars intermedia, and adrenal chromaffin cells. Proc Natl Acad Sci USA 2000; 97: 1281-6.

23. Samama B, Boehm N. Reelin immunoreactivity in lymphatics and liver during development and adult life. Anat Rec A Discov Mol Cell Evol Biol 2005; 285: 595-9.

24. Sato N, Fukushima N, Chang R, Matsubayashi H, Goggins $M$. Differential and epigenetic gene expression profiling identifies frequent disruption of the RELN pathway in pancreatic cancers. Gastroenterology 2006; 130: 548-65.

25. Stein T, Cosimo E, Yu X, et al. Loss of reelin expression in breast cancer is epigenetically controlled and associated with poor prognosis. Am J Pathol 2010; 177: 2323-33.

26. Serrano-Morales J, Vázquez-Carretero $M$, Peral $M$, Ilundáin A, García-Miranda P. Reelin-Dab1 signaling system in human colorectal cancer. Mol Carcinogen 2016; 56: 712-21.

27. Hong SE, Shugart YY, Huang DT, et al. Autosomal recessive lissencephaly with cerebellar hypoplasia is associated with human RELN mutations. Nat Genet 2000; 26: 93-6.

28. Impagnatiello F, Guidotti A, Pesold C, et al. A decrease of reelin expression as a putative vulnerability factor in schizophrenia. Proc Natl Acad Sci 1998; 95: 15718-23.

29. Guidotti A, Auta J, Davis J, et al. Decrease in reelin and glutamic acid decarboxylase67 (GAD67) expression in schizophrenia and bipolar disorder. Arch Gen Psychiatry 2000; 57: 1061-9.

30. Hornig T, Haas C, Sturm L, Fiebich B, Tebartz van Elst L. Increased blood-reelin levels in first episode schizophrenia. PLoS One 2015; 10: e0134671.

31. Botella-López A, Burgaya F, Gavin R, et al. Reelin expression and glycosylation patterns are altered in Alzheimer's disease. Proc Natl Acad Sci 2006; 103: 5573-8.

32. Kobold D, Grundmann A, Piscaglia F, et al. Expression of reelin in hepatic stellate cells and during hepatic tissue repair: a novel marker for the differentiation of HSC from other liver myofibroblasts. J Hepatol 2002; 36: 607-13.

33. Botella-López A, de Madaria E, Jover R, et al. Reelin is overexpressed in the liver and plasma of bile duct ligated rats and its levels and glycosylation are altered in plasma of humans with cirrhosis. Int J Biochem Cell Biol 2008; 40: 766-75.

34. Sui L, Ren W, Li B. Administration of thyroid hormone increases reelin and brain-derived neurotrophic factor expression in rat hippocampus in vivo. Brain Res 2010; 1313: 9-24.

35. Mashayekhi F, Gholizadeh L. Administration of hepatocyte growth factor increases reelin and Disabled 1 expression in the mouse cerebral cortex: an in vivo study. Cell Mol Neurobiol 2011; 31: 1267-70.

36. Ma Y, Wu X, Li X, et al. Corticosterone regulates the expression of neuropeptide $Y$ and reelin in MLO-Y4 cells. Mol Cells 2012; 33: 611-6. 